\title{
Efeito do anticorpo monoclonal 56G sobre o crescimento de Streptococcus mutans em caldo e no acúmulo de placa bacteriana in vitro Effect of monoclonal antibodies 56G on the growth of Streptococcus mutans in broth and on accumulation of dental plaque in vitro
}

\section{Antonio Carlos Victor CANETTIERI}

Professor da Disciplina de Imunologia e Microbiologia - Faculdade das Ciências da Saúde - UNIVAP - São José dos Campos.

\section{Fujiko Yamasiro KRETCHETOFF}

Mestrandro - Programa de Pós-Graduação em Biopatologia Bucal - Faculdade de Odontologia de São José dos Campos - UNESP - São José dos Campos - SP - Brasil

Professora da Disciplina de Microbiologia - Faculdade de Mogi das Cruzes- UMC

\section{Fabio Condino FUJARRA}

Mestrando - Programa de Pós-Graduação em Dor Orofacial - Departamento Neurologia - Hospital Clínicas - Faculdade de Medicina - USP - São Paulo - SP - Brasil

\section{Daniella MOREIRA}

Doutora em Biopatologia Bucal - Faculdade de Odontologia de São José dos Campos - UNESP - São José dos Campos $-\mathrm{SP}-$ Brasil

\section{Carmelinda Schmidt UNTERKIRCHER}

Professora Adjunta - Disciplina de Microbiologia e Imunologia - Faculdade de Odontologia de São José dos Campos - UNESP - São José dos Campos - SP - Brasil

\begin{abstract}
Resumo
$\mathrm{O}$ anticorpo monoclonal (Acmo) anti-Streptococcus mutans $56 \mathrm{G}$ foi analisado quanto ao efeito na aderência e crescimento da placa bacteriana in vitro, e quanto ao crescimento em caldo e no comprimento da cadeia do estreptococo. O Acmo foi purificado em proteína A - Sepharose e testado em ELISA frente a quatro cepas de S. mutans (ATCC 35668, SP, GS5, CD28A). O Acmo reconheceu com maior intensidade a cepa GS5. As placas bacterianas formadas in vitro na presença do Acmo apresentou menos carboidrato total (polissacarídeo extracelular) que o grupo controle e essa diferença foi significante $(p>0,001)$. A placa bacteriana do grupo tratado, formada sobre uma lamínula de vidro, era diferente da placa controle e apresentava agregados menores que cobriam a lamínula quase completamente. O Acmo $56 \mathrm{G}$ não influenciou o crescimento bacteriano, nem o comprimento da cadeia de $S$. mutans. Os resultados desse trabalho sugerem que o Acmo testado deve reconhecer a glicosiltransferase (GTF) de S. mutans presente na superfície bacteriana, interferindo na síntese de glucano por essa enzima.
\end{abstract}

\section{UNITERMOS}

Streptococcus mutans; anticorpo monoclonal; cárie dentária

\section{INTRODUÇÃO}

O Streptococcus mutans tem sido considerado a principal espécie bacteriana envolvida na cárie dentária, sendo frequientemente isolado de dentes humanos $^{10}$. O potencial patogênico de $S$. mutans foi aumentado pela habilidade em produzir polissacarídeos extracelulares derivados da sacarose, através da ação de três glicosiltransferases (GTF): a GTF-I (codificada pelo gene gtf B) produz glucano insolúvel em água, denominado mutano; a GTF-S (produto do gene gtf-D) sintetiza um produto similar ao dextrano e na maioria das vezes hidrossolúvel; e a GTF-SI (codificada por gtf-C) produz uma mistura de glucano solúvel e insolúvel em água ${ }^{19}$. Os glucanos produzidos por $S$. mutans facilitam a aderência e o acúmulo de microrganismos, estabelecendo uma matriz extracelular resistente às forças mecânicas normais de remoção presentes no hospedeiro, e proporcionando alguma proteção contra o sistema imune e defesas não imunes ${ }^{5}$. O único habitat natural conhecido de $S$. mutans é a superfície dentária. Esses microrganismos não são encontrados na cavidade bucal antes da erupção dos dentes e uma única cepa de $S$. mutans pode colonizar um hospedeiro 
por longo período de tempo ${ }^{4,6,11}$. O estudo detalhado da estrutura antigênica de $S$. mutans é de extremo interesse público e o desenvolvimento de anticorpos monoclonais especificamente dirigidos para certos componentes bacterianos permitirá novas abordagens terapêuticas no campo da Odontologia.

O presente estudo teve como objetivo analisar a influência do Acmo 56G anti-S. mutans no processo de formação de placa in vitro sobre superfície vítrea, assim como, no crescimento em caldo e no comprimento da cadeia do estreptococo.

\section{Material e método}

\section{Anticorpo monoclonal}

$\mathrm{O}$ anticorpo monoclonal $56 \mathrm{G}$ anti-S. mutans (IgG2b) estudado foi desenvolvido no laboratório de Imunologia da Faculdade de Odontologia de São José dos Campos - UNESP, pela Técnica de Hibridomas $^{8,13-15}$.

\section{Produção da ascite}

Para a produção da ascite foi injetado $0,5 \mathrm{ml}$ de pristane por via intra peritoneal, em cinco camundongos BALB/c com oito semanas de idade. No décimo dia consecutivo, foram injetadas dez $^{6}$ células do clone produtor de anticorpo previamente selecionado. Aguardou-se o período de duas a três semanas e a seguir, a ascite foi colhida (5 a $10 \mathrm{ml}$ de ascite por camundongo), centrifugada e estocada a $-20^{\circ} \mathrm{C}$, após a adição de azida sódica a $0,02 \%$. Este trabalho foi aprovado pelo Comitê de Ética em Pesquisa da Faculdade de Odontologia de São José dos Campos - UNESP (008/98 - PA/CEP)

\section{Purificação do Acmo}

O Acmo 56G foi purificado em coluna de Sepharose-proteína A (Pharmacia), aplicando-se lentamente o fluído ascítico diluído a 1/15 em tampão fosfato $0,02 \mathrm{M}, \mathrm{pH} 7,0$, por 2 horas, a $4^{\circ} \mathrm{C}$. O anticorpo foi eluído com glicina-ácido clorídrico, $0,1 \mathrm{M}, \mathrm{pH} 2,8$ e o eluato neutralizado com 2,3 dibromopropil-ácido clorídrico (Tris-HCl) 1M, pH 9,0. Em seguida, dialisou-se o material contra solução salina tamponada com fosfato (PBS) por uma noite, a 40C. A concentração de Acmo foi determinada por espectrofotometria, a 280nm (UV-1203-Shimadzu).

\section{Streptococcus mutans}

\section{ELISA}

Quatro cepas de S. mutans (GS5, SP, ATCC35668, CD28A) foram analisadas em relação a reatividade com o Acmo em ELISA, com a finalidade de selecionar a cepa que seria utilizada no estudo. Placas de polivinil (COSTAR) com 96 orifícios, previamente sensibilizadas com as cepas de estreptococos, tiveram os sítios livres bloqueados com $0,5 \%$ de gelatina em PBS. O Acmo diluído em PBS $(20 \mu \mathrm{g} / \mathrm{ml})$ contendo $0,1 \%$ de Tween-20 e gelatina (PBS-T-G) foi adicionado, em quadruplicata, nos primeiros orifícios realizando-se diluições consecutivas na razão dois. Após duas horas e lavagens com PBS-T, adicionouse anti-IgG de camundongo marcado com peroxidase (SIGMA) (1/2000). A atividade da peroxidase foi revelada utilizando-se ortofenilenodiamino (SIGMA) em tampão citrato-ácido cítrico $0,1 \mathrm{M}, \mathrm{pH} 5,5$ e peróxido de hidrogênio $0,003 \%$. A reação foi bloqueada com ácido sulfúrico $2,5 \mathrm{~N}$. As densidades ópticas foram lidas a 490nm, num leitor ELISA modelo 3550 (BIO RAD). No ELISA utilizou-se como controle negativo, um anticorpo monoclonal irrelevante (não-específico para $S$. mutans) purificado em proteína A e testado nas mesmas concentrações que o Acmo em teste.

\section{Estudo da formação de placa bacteriana in vitro}

Em tubos de ensaio $(n=10)$ contendo caldo sacarosado $^{7}$ e um corpo de prova (bengala de vidro esterilizada) foi introduzido uma alíquota de Acmo $(100 \mu \mathrm{g} / \mathrm{ml})$. Após agitação, acrescento-se $50 \mu 1$ de $S$. mutans, crescido em caldo tríptico de soja (TSB-Difco) por 24 horas. $O$ grupo controle recebeu apenas a alíquota de $50 \mu \mathrm{l}$ de $S$. mutans. Todos os tubos foram incubados a 370C, em microaerofilia, por 24 horas. Após esse período, as bengalas de vidro foram removidas do interior dos tubos de ensaio com o auxílio de alça de platina, lavadas cuidadosamente em solução salina $0,85 \%$ esterilizada, sendo posteriormente depositados em novos tubos contendo $1 \mathrm{ml}$ de solução salina esterilizada. Cada tubo foi agitado por um minuto para que a placa bacteriana formada se desprendesse do corpo de prova. A quantidade de placa foi avaliada pela mensuração do conteúdo protéico e glicídico e, posteriormente, semeadas em Agar Mitis salivarius (MSADifco), a fim de se analisar as unidades formadoras de colônias (UFC). Na análise protéica, utilizou-se o método preconizado por Bradford1 (1976), que usa como padrão BSA (albumina bovina-MILES) na con- 
centração de $100 \mu \mathrm{g} / \mathrm{ml}$. A quantidade de carboidrato total da placa foi dosada pelo método da antrona 18 , que utiliza manose $(1 \mathrm{mg} / \mathrm{ml})$ como padrão. Utilizou-se a absorbância de 590nm para determinar o conteúdo total de carboidrato na amostra.

\section{Semeadura das amostras de placa em MSA}

Cerca de $0,1 \mathrm{ml}$ da amostra de placa do grupo controle e do grupo tratado com $56 \mathrm{G}$ foi diluído em $1 \mathrm{ml}$ de solução salina $0,85 \%$ (diluição $10^{-1}$ ). $\mathrm{O}$ tubo foi, então, agitado em vortex e uma alíquota de $0,1 \mathrm{ml}$ foi transferida para um novo tubo com $1 \mathrm{ml}$ de solução salina (diluição a $10^{-2}$ ). Repetiu-se esse processo por mais uma vez (diluição a $10^{-3}$ ). Após, $0,1 \mathrm{ml}$ dos tubos das diluições a $10^{-2}$ e $10^{-3}$ foram semeados, em duplicata, em placas de Petri contendo MSA. Todas as placas foram incubadas em lata com vela, a 370C, por no máximo 72 horas. Após esse período as UFC foram contadas no contador de colônias (Phoenix) e calculou-se, após, a média de cada duplicata.

\section{Efeito do Acmo $56 \mathrm{G}$ sobre o crescimento em caldo e comprimento da cadeia de $S$. mutans (GS5)}

Em dez tubos de ensaio de fundo reto foi inserida uma lamínula de vidro. Os tubos foram autoclavados (1210C, 15min) e, posteriormente, no interior de uma câmara de fluxo laminar, preenchidos com $1 \mathrm{ml}$ de caldo sacarosado. Cinco tubos receberam o Acmo 56G $(100 \mu \mathrm{g} / \mathrm{ml})$ e, na sequência, $50 \mu \mathrm{l}$ de uma cultura, em TSB, de $S$. mutans GS5 de 24 horas. Outros cinco tubos receberam um Acmo inespecífico para $S$. mutans e a cultura bacteriana. Todos os tubos foram incubados, a 370C, por 24 horas. Após, foram realizados, com o auxílio de alça de platina, dois esfregaços em lâmina de cada amostra, que foram posteriormente corados pelo Método de Gram, para analisar a pureza da cultura e o comprimento de cadeia dos estreptococos. $\mathrm{O}$ comprimento médio da cadeia foi determinado usando microscópio de luz em aumento de 1000X com imersão, através da contagem do número de bactéria por cadeia, em dez cadeias, em cada esfregaço ${ }^{20}$. Os tubos foram agitados por 5 segundos e o conteúdo de cada um depositado em eppendorfs, que foram centrifugados por 5 minutos a 5.000rpm (microcentrífuga- DU PONT). Os sedimentos foram ressuspensos em $400 \mu \mathrm{l}$ de PBS e agitados por 30 segundos em vortex e, imediatamente, alíquotas de $100 \mu \mathrm{l}$ da amostra foram adicionadas em placa de ELISA, em duplicata. A DO do crescimento celular das amostras foi medido a 590nm e calculou-se depois, a DO média de cada duplicata ${ }^{20}$.

Finalmente removeu-se, com auxílio de alça de platina, as lamínulas dos fundos dos tubos de ensaio. Cada lamínula foi corada pelo método de Gram e analisou-se o aspecto da placa formada nos dois grupos estudados em microscópio de luz (aumentos de 100x, 200x, 400x).

\section{Análise estatística}

Os dados obtidos nos experimentos de dosagem protéica e carboidrato foram analisados por ANOVA e quando necessário, foi aplicado o teste de Tukey. O nível de significância adotado foi de 5\%. Aplicou-se teste $t$-student para os dados provenientes dos experimentos referentes a UFC/ml e taxa de crescimento bacteriano em caldo. $\mathrm{O}$ nível de significância adotado foi de $5 \%$.

Realizou-se o teste de correlação de Spearman com os dados provenientes das contagens de UFC/ml, teor protéico e quantidade de carboidrato da placa, para averigüar se havia alguma relação entre essas variáveis.

\section{Resultados}

A Figura 1 mostra a média da reatividade do Acmo $56 \mathrm{G}$ frente às cepas de $S$. mutans GS5, ATCC 35668, CD28 e SP. Cada experimento foi realizado em quadruplicata e elegemos a concentração $5 \mu \mathrm{g} / \mathrm{ml}$ para a análise. O Acmo reagiu com as quatro cepas, pois o nível de reatividade foi superior ao valor do controle negativo (cut off). A cepa de $S$. mutans que mais reagiu com o Acmo 56G foi a GS5. Esses dados não foram analisados estatisticamente, pois se originaram de um único experimento. 
EFEITO DO ANTICORPO MONOCLONAL 56G SOBRE O CRESCIMENTO DE STREPTOCOCCUS MUTANS EM CALDO E NO ACÚMULO DE PLACA BACTERIANA IN VITRO

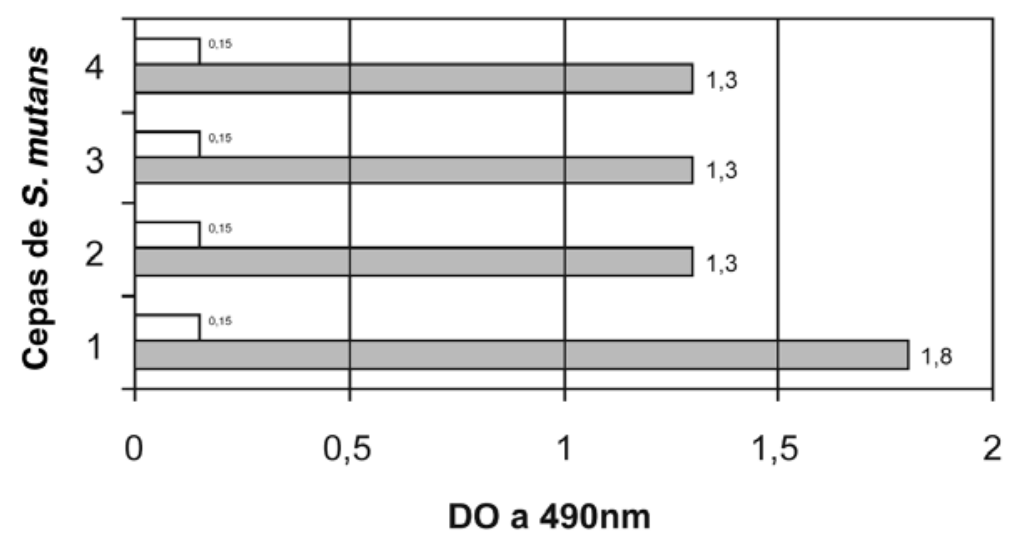

\section{$\square$ Acmo 56G $\square$ Acmo irrelevante}

FIGURA 1 - ELISA- Média da reatividade do Acmo 56G e do Acmo irrelevante (controle negativo) frente as quatro cepas de S. mutans estudadas: 1) GS5, 2) SMSP, 3) CD28, 4) ATCC 35668.

A Figura 2 mostra a quantidade de placa, em $\mu \mathrm{g} /$ $\mathrm{ml}$, formada no grupo controle (sem anticorpo) e na presença de anticorpo anti-S. mutans. A placa formada na presença do Acmo $56 \mathrm{G}$ continha mais proteína, mas não houve diferença estatística significante entre o grupo tratado com o Acmo e o grupo controle.

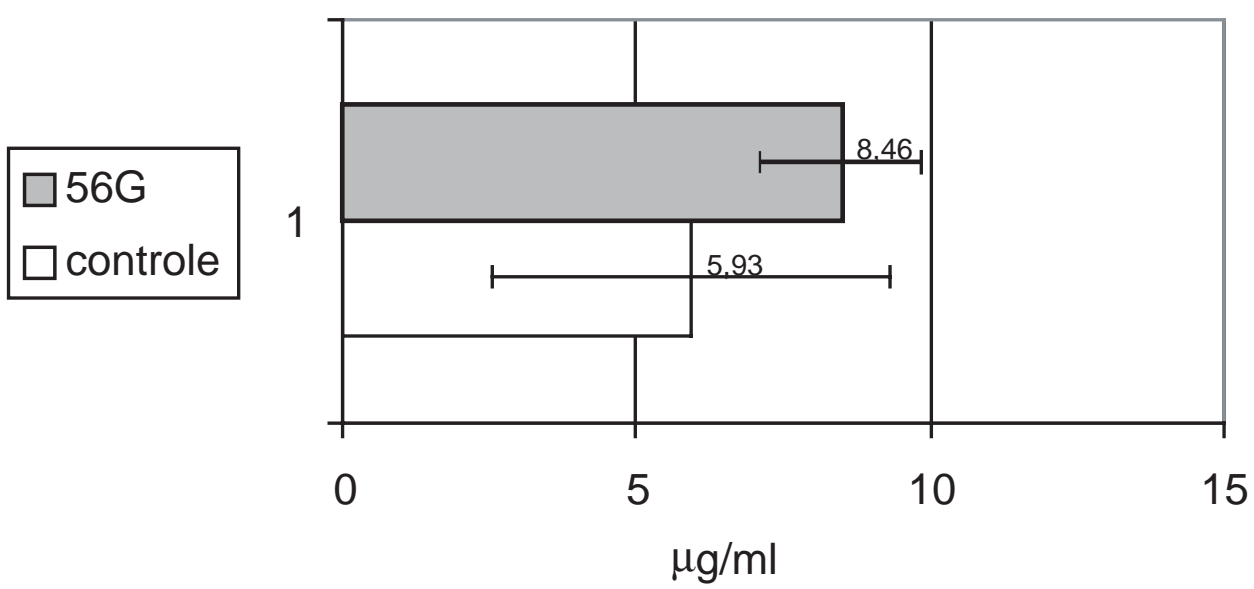

FIGURA 2 - Média das dosagens protéica das placas dos grupos controle e tratado com 56G.

A Figura 3 revela que a placa formada na presença do Acmo continha menos carboidrato total (polissacarídeo extracelular) e houve diferença estatisticamente significante quando comparada a placa controle $(\mathrm{p}<0,001)$. 


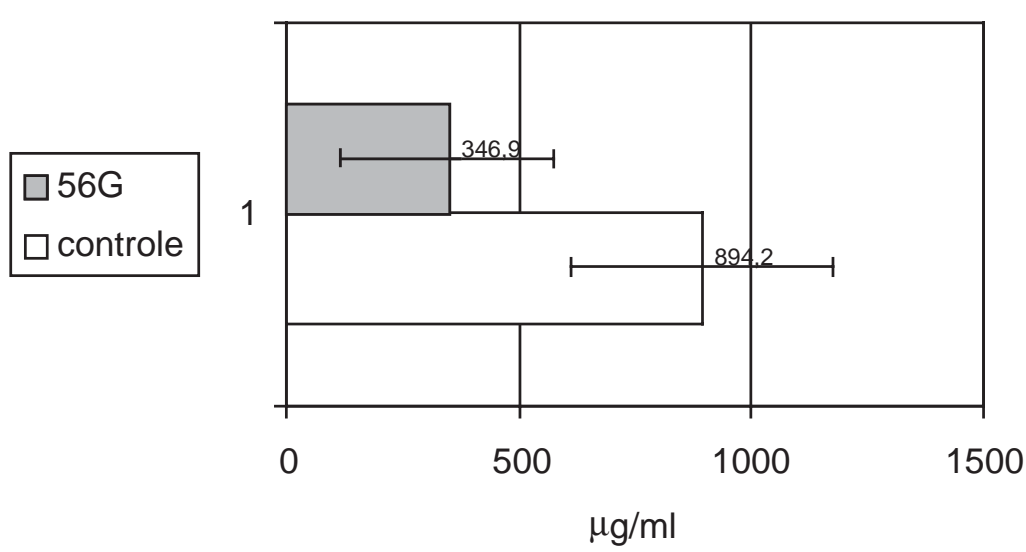

FIGURA 3 - Media das Dosagens de carboidrato das placas dos grupos controle e tratado com 56G. Diferença significante: p<0,001.

Apesar da placa formada na presença do Acmo $56 \mathrm{G}$ apresentar uma média maior de $\mathrm{UFC} / \mathrm{ml}$, não houve diferença estatística quando comparada ao grupo controle $(\mathrm{p}=0,933)$. Deve-se destacar também a enorme variação de UFC existente detectada na placa com 56G (valor mínimo=3800 UFC/ml, valor máximo=3.350.000 UFC/ml) (Figura 4)

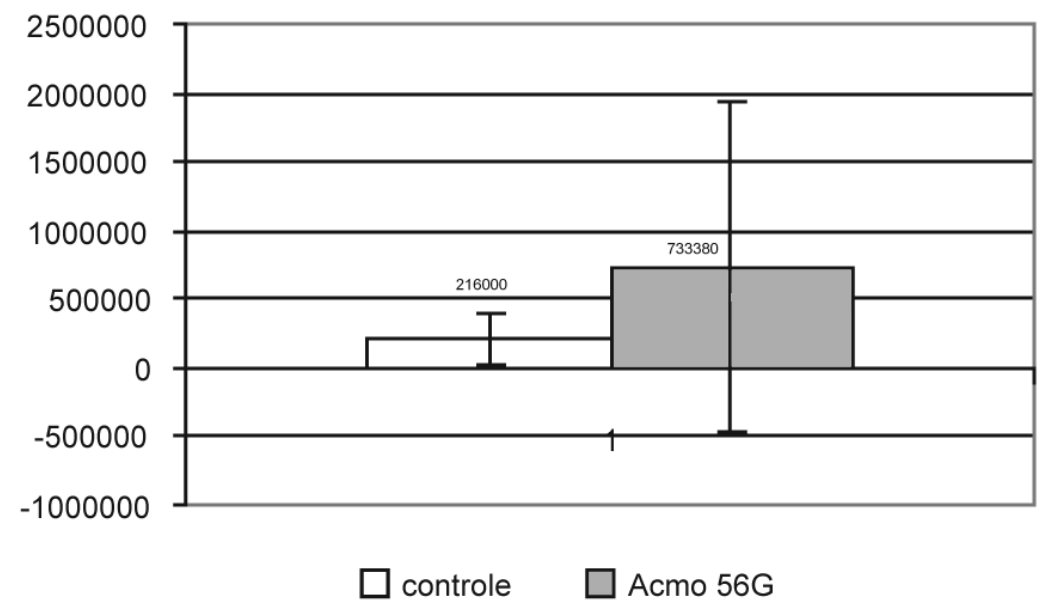

Figura 4 - Média das UFC/ml presentes nas placas dos grupos controle e tratado com 56G

Quando se aplicou o teste de correlação de Spearman, não se obteve relação entre proteína X carboidrato X UFC na placa bacteriana controle e naquela formada na presença de $56 \mathrm{G}(\mathrm{p}>0,050)$.

A placa bacteriana do grupo controle formada sobre uma lamínula de vidro e corada pelo método de Gram (Figura 5) mostrou-se diferente da placa formada sob influência do Acmo 56G (Figura 6). A placa do grupo controle apresentava-se como uma mistura de agregados bacterianos maiores e menores que deixavam áreas da lamínula de vidro descoberta, sendo mais fácil observar, nos maiores aumentos, cadeias de estreptococos nesses espaços vazios. A placa do grupo tratado com Acmo 56G continha agregados menores que os do controle, que cobriam a lamínula quase totalmente. 


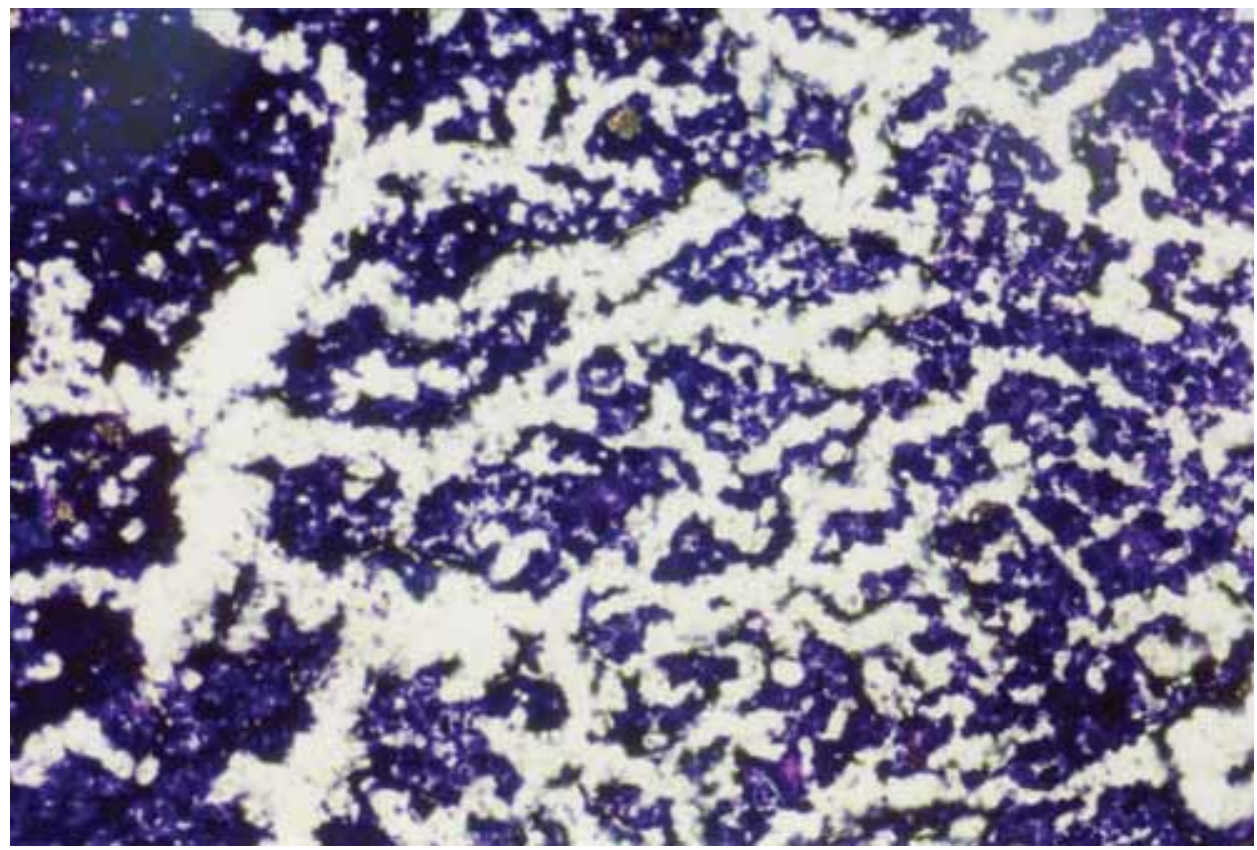

FIGURA 5 - Placa bacteriana do grupo controle, 100X. (Coloração de Gram)

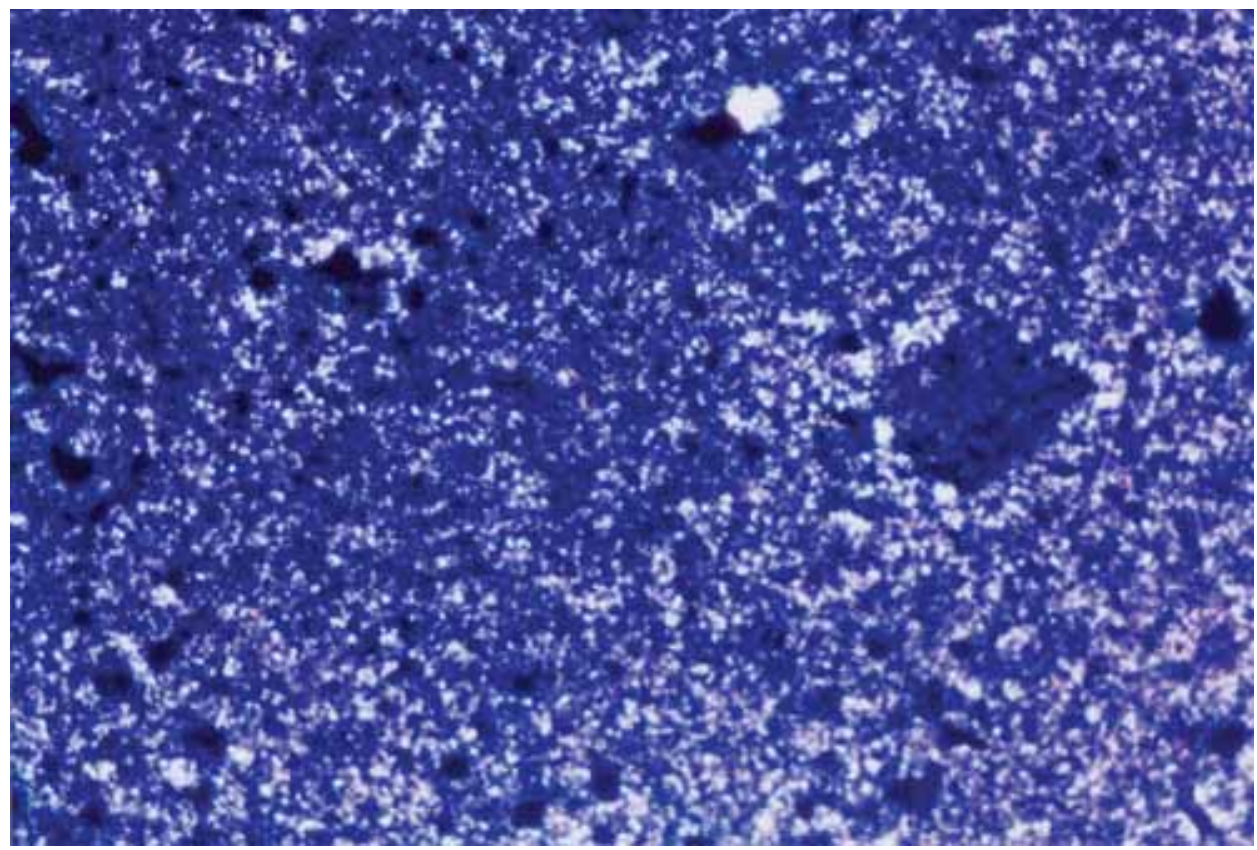

FIGURA 6-Placa bacteriana do grupo 56G, 100X. (Coloração do Gram)

Não se obteve diferença estatística significante entre as densidades ópticas (Tabela 1) das suspensões bacterianas obtidas a partir do crescimento bacteriano em caldo no grupo controle e no grupo que recebeu o Acmo 56G ( $\mathrm{p}=0,837)$. O Acmo 56G também não influenciou o comprimento da cadeia do estreptococo, pois os resultados obtidos nos dois grupos foram idênticos. 
Tabela 1 - Média das DO do crescimento bacteriano com e sem anticorpo

\begin{tabular}{c|c}
\hline Controle & $56 \mathrm{G}$ \\
\hline 0,376 & 0,382 \\
0,269 & 0,394 \\
0,370 & 0,439 \\
0,541 & 0,433 \\
0,435 & 0,392 \\
\hline
\end{tabular}

\section{Discussão}

O estudo aqui apresentado envolveu um Acmo e quatro cepas de $S$. mutans, sendo a cepa GS5 a mais reconhecida pelo Acmo 56G. A cepa GS5, sorotipo c, é internacionalmente reconhecida como defectiva para a proteína $\mathrm{P} 1$, uma adesina responsável pela aderência de $S$. mutans à película salivar que recobre a hidroxiapatita dentária ${ }^{15-6}$.

Koga et al. ${ }^{12}$ (1990) constataram que cepas defectivas ou não em P1 eram capazes de aderir firmemente ao vidro na presença de caldo sacarosado, mostrando que P1 não participava da aderência dependente de sacarose. Experimentos realizados por Crowley ${ }^{3}$, 1999, também mostraram que uma cepa mutante de $S$. mutans, negativo para P1, era capaz de colonizar a superfície dentária murina na ausência ou presença da célula do tipo selvagem, reforçando o conceito de aderência mediada por polímeros extracelulares (glucanos), quando a sacarose está presente no meio. $\mathrm{Na}$ ausência de sacarose a proteína P1 desempenharia um papel maior na colonização da superfície dentária. Tais observações foram confirmadas em nossos experimentos quando comparamos as quatro cepas em relação à quantidade de carboidrato da matriz extracelular do biofilme. A cepa GS5, defectiva para $\mathrm{P} 1$, formou biofilme em superfície vítrea, com meio sacarosado, do mesmo modo que as demais cepas não defectivas (dados não apresentados).

A placa formada na presença do Acmo apresentou menos carboidrato total, possivelmente polissacarídeo extracelular, o que se pôde pensar numa inibição das GTF de $S$. mutans pelo Acmo, que teve a capacidade de reduzir a síntese de glucano, mas não inibiu a aderência pelo mecanismo dependente de sacarose presente no meio de cultura. $\mathrm{O}$ mecanismo de aderência saca- rose-dependente ainda não foi bem esclarecido, mas os Acmo acrescentados podem ter reagido com o sítio ativo da enzima GTF e/ou mudado sua configuração para um estado menos ativo levando a uma redução da síntese de glucano sem interferir na aderência bacteriana. Ochiai ${ }^{17}$ (1990) desenvolveram quatro Acmo reativos com a GTF-I de S. sobrinus B13 e apenas um Acmo inibiu a síntese de glucano-insolúvel em 50\%, mas foi incapaz de inibir a aderência de células mortas pelo calor ao vidro, mediada pela GTF-I exógena. Um outro Acmo (IgG2a), apesar de se ligar a GTF-I, não mostrou qualquer efeito inibitório na síntese de glucano, mas foi o único efetivo na inibição da aderência celular. Chia ${ }^{2}$ (1993) mostraram ainda que o Acmo, que inibiu especificamente a GTF-SI, não teve efeito na GTF-S, embora ambas apresentassem a mesma região peptídica reconhecida pelo $\mathrm{Acmo}$. Isso sugeriu que um Acmo pode se ligar a um mesmo epítopo presente em diferentes GTF, mas que o efeito final dessa ligação na atividade da enzima pode variar, porque as GTF podem ter sequências primárias idênticas, mas estruturas conformacionais diferentes.

Na tentativa de avaliar a proporção de células presentes na matriz da placa dentária, aplicamos o teste estatístico de Spearman. Entretanto nenhuma relação foi observada entre UFC, teor protéico e teor de carboidrato na placa controle, nem nas placas formadas em presença de 56G. A placa do grupo 56G apresentou uma quantidade média de proteína e UFC/ml maior que o grupo controle, mas essas diferenças não foram estatisticamente significantes. Esse aumento de proteína na placa era esperado devido à presença do Acmo $56 \mathrm{G}$, o que pode ter favorecido a ligação de bactérias planctônicas (da fase fluida), provocando o aumento não significante, mas existente na média de UFC/ml na placa do grupo 56G. Esse mecanismo de ligação já 
foi proposto por Lehner et al. ${ }^{15}$ (1985) e $\mathrm{Ma}^{16}$ (1990). Um fato curioso foi a enorme variação de UFC nas amostras do grupo 56G. Foi identificado desde 3800 $\mathrm{UFC} / \mathrm{ml}$ até $3.350 .000 \mathrm{UFC} / \mathrm{ml}$. Talvez isso tenha acontecido pela quebra incompleta da cadeia de estreptococo, mesmo após agitação por $1 \mathrm{~min}$. Os resultados obtidos em relação às $\mathrm{UFC} / \mathrm{ml}$ dos grupos tratado e controle podem não ser verdadeiros, sendo "UFC" uma variável difícil de ser discutida e analisada, pelo menos com a metodologia adotada.

O Acmo 56G não interferiu na taxa de crescimento bacteriano, nem no comprimento da cadeia de $S$. mutans, quando comparado ao grupo controle. Microscopicamente, as cadeias bacterianas do grupo controle e do grupo tratado eram idênticas, sem haver a formação de aglomerados. Van Raamsdonk ${ }^{20}$ (1997) verificaram que a adição de anticorpos policlonais para S. sobrinus, durante o crescimento bacteriano em caldo, não influenciava a taxa de crescimento, mas levava a formação de cadeias significantemente mais longas, o que não foi observado em nosso experimento.

Outra característica interessante foi a diferença na estrutura da placa bacteriana, formada sobre uma lamínula e corada pelo método de Gram, entre o grupo controle e o grupo tratado com $56 \mathrm{G}$. A placa crescida na presença do Acmo continha agregados bacterianos menores e cobria quase completamente a lamínula de vidro. Hazlett et al. ${ }^{9}$ (1999) inativaram o gene que codifica uma proteína de $59 \mathrm{kDa}$, a GbpA (proteína A ligada ao glucano) e observaram alteração na estrutura da placa de $S$. mutans, que se apresentou como uma camada uniforme de agregados menores, cobrindo totalmente a superfície estudada. A bactéria do tipo selvagem cresceu, na presença de sacarose, formando um biofilme, com agregados largos que não cobriam completamente a superfície da hidroxiapatita. Apesar da diferença de técnica usada para estudar a formação de placa, as semelhanças entre os resultados alcançados são marcantes. A Gbpa é uma proteína, não enzimática, secretada pelo $S$. mutans e encontrada em associação com a superfície celular e no meio extracelular. Possui na região carboxi-terminal um domínio de ligação ao glucano (GBD) homólogo ao da GTF. $\mathrm{O}$ Acmo 56G, em estudo, pode ter provocado uma alteração na estrutura da placa bacteriana (bloqueio da GTF e da GbpA), mas é necessário confirmar estas suspeitas de forma experimental.

Estudos posteriores poderão determinar se o Acmo 56G inibiu completa ou parcialmente a síntese de glucano hidrossolúvel ou do glucano-insolúvel em água (mutano). Baseados nos dados da literatura, já apresentados, pode-se sugerir que o Acmo ao se ligar a GTF, não bloqueou totalmente a síntese de glucano por essas enzimas, nem a aderência sacarose-dependente, sendo interessante determinar se o Acmo pode reconhecer de maneira exclusiva uma GTF, dado que seria de extrema utilidade em estudos epidemiológicos sobre placa dentária e cárie em humanos.

\section{Conclusões}

O Acmo $56 \mathrm{G}$ foi mais reativo com a cepa GS5 e reduziu, in vitro, a quantidade de carboidrato total presente na placa bacteriana, mas falhou em inibir a aderência sacarose-dependente de S. mutans ao vidro. O Acmo 56G modificou também a estrutura da placa bacteriana, que se apresentou mais uniforme e com agregados bacterianos menores que os do grupo controle.

\begin{abstract}
The effect of a monoclonal antibody (Mab) against $\mathrm{S}$. mutans $(56 G)$ was investigated on attachment to and accumulation of dental plaque in vitro, and on the growth in broth and chain length of S. mutans. Purified Mab was analysed in ELISA in relation of four S. mutans strains (ATCC 35668, SP, GS5, CD28A). Mab recognised with higher intensity GS5 strain. The dental plaques developed in the presence of Mab 56G showed less total carbohydrate (extracellular polysacharides) when compared with control group and there was statistical significance ( $p>0,001)$. Control dental plaques formed on cover glass were different of $56 \mathrm{G}$ dental plaques, which displayed smaller aggregates that almost entirely coated the cover glass. Acmo $56 G$ did not influence the chain length, neither the growth of S. mutans. Results suggest that studied Mab should recognize cell-bound $\mathrm{S}$. mutans glucosyltransferase (GTF), influencing glucan synthesis by these enzymes.
\end{abstract}

\title{
UNITERMS
}

Streptococcus mutans; monoclonal antibody; dental decay. 


\section{REFERÊNCIAS}

1. Bradford MM. A rapid and sensitive method for the quantification of microgram quantities of protein utilizing the principle of protein-dye binding. Anal Biochem. 1976 May; 7(72):248-54.

2. Chia JS. Inhibition of glucosyltransferase actives of Streptococcus mutans by a monoclonal antibody to a subsequence peptide. Infect Immun. 1993 Nov.; 61(11):4689-95.

3. Crowley PJ. Virulence of a spaP mutant of Streptococcus mutans in a gnotobiotic rat model. Infect Immun. 1999 Mar.; 67(3):1201-6.

4. De Soet JJ, de Graaff J. Microbiology of carious lesions. Dent Update. 1998 Oct.; 25(8):319-24.

5. DuPont GA. Understanding dental plaque; biofilm dynamics. J Vet Dent. 1997 Sept.; 14(3):91-3.

6. Emanuelsson IR, Thornqvist E. Genotypes of mutans streptococci tend to persist in their host for several years. Caries Res. 2000 Mar.; 34(2):133-9.

7. Gibbons RJ, Nygaard M. Synthesis of insoluble dextran and its significance in the formation of gelatinous deposits by plaque- forming streptococci. Archs Oral Biol. 1968 Oct.; 13:1249-62.

8. Goding JW. Antibody production by hybridomas. J Immunol Methods. 1980 Aug.; 39(4):285-308

9. Hazlett KRO, Mazurkiewicz JE, Banas JA. Inactivation of the gbpA gene of Streptococcus mutans alters structural and functional aspects of plaque biofilm wich are compensated by recombination of the gtfB and gtfC genes. Infect Immun. 1999 Aug.; 67(8):3909-14.

10 Jorge AOC. Microbiologia bucal. São Paulo: Ed. Santos, 1988.

11 Karn TA. Colonization of mutans streptococci in 8- to 15- month- old children. J Public Health Dent.1998; 58(3):248-9.

12 Koga T. Surface hydrophobicity, adherence, and aggregation of cell surface protein antigen mutants of Streptococcus mutans serotype c. Infect Immun. 1990 Feb.; 58(2):289-96.
13 Köhler G, Milstein C. Continuos cultures of fused cells secreting antibody of predifined specificity. Nature.1975 Aug.; 256(7):495-7.

14 Köhler G, Howe SC, Milstein C. Fusion between immunoglobulinsecreting and nonsecreting myeloma cell lines. Eur J Immunol.1976 Apr.; 6(4):292-5.

15 Lehner T, Caldwell J, Smith R. local passive immunization by monoclonal antibody against streptococcal antigen I/II in the prevention of dental caries. Infect Immun. 1985 Dec.; 50(3): 796-9.

16 Ma JKC. The caries vaccine: a growing prospect. Dent Update.1999 Nov.; 26(9):374-80.

17 Ochiai K. Characterization of monoclonal antibodies against glucosyltransferase synthesizing water-insoluble glucan from Streptococcus mutans B13. J Dent Res. 1990 Feb.; 69(2):477-82.

18 Pons A. A method for the simultaneous determination of total carbohydrate and glycerol in biological samples with anthrone reagent. J Biochen Biophys Methods. 1981 Mar.; 4(3):227-31.

19 Tomita Y. Evaluation of three individual glucosyltransferases produced by Streptococcus mutans using monoclonal antibodies. FEMS Microbiol Lett. 1996 Dec.; 145(3):427-32.

20 van Raamsdonk. Effect of antibodies on the chain length and growth of streptococcus mutans. Caries Res. 1997; 31(1):35-40.

Recebido em:29/05/05 Aprovado em: 20/12/05

Antonio Carlos Victor Canettieri Av. Salmão - 472 - apto - 112 Tel: (12) 3911-2952. acanettieri@directnet.com.br Parque Residencial Aquários São José dos Campos - SP. - Brasil $12246-260$ 